\title{
PENGARUH DEWAN KOMISARIS, KOMPOSISI DEWAN KOMISARIS INDEPENDEN, DEWAN PENGAWAS SYARIAH, FREKUENSI RAPAT DEWAN KOMISARIS SYARIAH, DAN FREKUENSI RAPAT KOMITE AUDIT TERHADAP PENGUNGKAPAN INDEKS ISLAMIC SOCIAL REPORTING PADA BANK UMUM SYARIAH PERIODE 2010-2014 1)
}

\author{
Wardatul Baidok \\ Program Studi Ekonomi Islam-Fakultas Ekonomi dan Bisnis-Universitas Airlangga \\ Email:warda172@gmail.com \\ Dina Fitrisia Septiarini \\ Departemen Ekonomi Syariah-Fakultas Ekonomi dan Bisnis-Universitas Airlangga \\ Email: dina.fitrisia@gmail.com
}

\begin{abstract}
:
This study aims to find out the simultaneous and partial influences of aboard of commissioner, the composition of board of independent commissioner, board of syariah controller, the frequency of board of syariah controller meetings, and the frequency of audit committee meetings toward the disclosure of ISR index to Islamic public banks during period 2010-2014.

This study uses quantitative approach, and the data is a secondary data which was obtained using purposive sampling. The data was analyzed using panel data regression. The population includes all Islamic public banks in Indonesia by focusing on period 2010-2014.

The result shows that, simultaneously, the five variables have significant influence toward ISR. Partially, KDKI, DPS, and the FRDPS have significant influence toward ISR, while DK and FRKA have insignificant influence toward ISR.

Keywords: Good Corporate Governance, disclosure, Islamic Social Reporting index, Islamic Public Bank
\end{abstract}

\section{PENDAHULUAN}

\section{Latar Belakang}

Kegiatan muamalah telah banyak mengalami perkembangan, salah satunya adalah kegiatan perbankan.Kegiatan perbankan mulai berkembang dengan berdirinya bank syariah sebagai bank tanpa bunga (riba) yang kegiatan usahanya berdasarkan prinsip syariah dan berpedoman pada Al-Qur'an dan Hadits, dimana bunga (riba) diharamkan karena bermakna ziyadah atau tambahan (Ismail, 2011:11). Hal tersebut sesuai dengan Firman Allah yang dijelaskan secara tersirat dalam surat Al-Baqarah ayat 278-279:

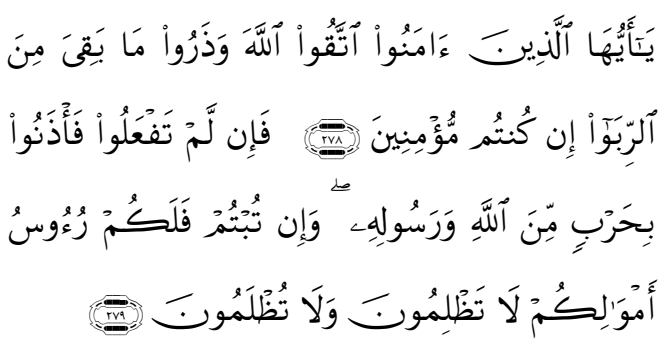

Yā-'ayyuhā'llażīna

'āmanūttaqū'llāha wa-żarū mā baqiya mina'rribā in kuntum mu'minin. Fa-'in lam taf'alū fa-'żanū bi-harbin mina'llāhi wa-rasūlihì wa-'in tubtum fa-lakum ru'ūsu 'amwālikum lā tazlimūna wa-lā tużlamūn

Artinya: "Hai orang-orang yang beriman, bertakwalah kepada Allah dan tinggalkan sisa Riba (yang belum dipungut) jika kamu orang-orang yang beriman. Maka jika kamu tidak mengerjakan (meninggalkan sisa riba), Maka ketahuilah, bahwa Allah dan Rasul-Nya akan memerangimu. dan jika kamu bertaubat (dari

1) Jurnal ini merupakan bagian dari skripsi dari Wardatul Baidok, NIM : 041211431176 , yang diuji pada 3 Juni 2016. 
Baidok, et al/Jurnal Ekonomi Syariah Teori dan Terapan Vol. 3 No. 12 Desember 2016: 1020-1034; PENGARUH DEWAN KOMISARIS, KOMPOSISI DEWAN KOMISARIS INDEPENDEN, DEWAN PENGAWAS SYARIAH, FREKUENSI RAPAT DEWAN KOMISARIS SYARIAH, DAN FREKUENSI RAPAT KOMITE AUDIT TERHADAP PENGUNGKAPAN INDEKS ISLAMIC SOCIAL REPORTING PADA BANK UMUM SYARIAH PERIODE 2010-2014

pengambilan riba), maka bagimu pokok hartamu; kamu tidak menganiaya dan tidak (pula) dianiaya." (Q.S. $\quad$ 02: 278-279, Departemen Agama RI 2010:47).

Ayat diatas menjelaskan secara

tegas bahwa Allah melarang dengan keras semua jenis riba, bahkan Allah dan Rasul-Nya memerangi orang-orang yang masih mengambil sisa-sisa riba.

Bank syariah di Indonesia terdiri dari tiga jenis bank, yaitu Bank Umum syariah (BUS), Unit usaha Syariah (UUS), dan Bank Perkreditan Rakyat Syariah (BPRS). Berikut disajikan dalam tebel 1.1 di bawah ini:

Tabel 1.

Perkembangan Perbankan Syariah di Indonesia

Tahun 2009 - Juni 2015

\begin{tabular}{|l|r|r|r|r|r|r|r|}
\hline \multicolumn{1}{|c|}{ Indikator } & $\mathbf{2 0 0 9}$ & $\mathbf{2 0 1 0}$ & $\mathbf{2 0 1 1}$ & $\mathbf{2 0 1 2}$ & $\mathbf{2 0 1 3}$ & $\begin{array}{r}\mathbf{2 0 1 4} \\
\text { (Des) }\end{array}$ & $\begin{array}{r}\mathbf{2 0 1 5} \\
\text { (Juni) }\end{array}$ \\
\hline $\begin{array}{l}\text { Bank Umum Syariah } \\
\text { - Jumlah Bank } \\
\text { - Jumlah Kantor } \\
\text { Unit Usaha Syariah } \\
\text { - Jumlah Bank Umum }\end{array}$ & 6 & 11 & 11 & 11 & 11 & 12 & 12 \\
$\begin{array}{l}\text { Konvensional } \\
\text { yang memiliki UUS }\end{array}$ & 711 & 1.215 & 1.401 & 1.745 & 1.998 & 2.151 & 2.121 \\
$\begin{array}{l}\text { - Jumlah Kantor } \\
\text { Bank Pembiayaan Rakyat } \\
\text { Syariah }\end{array}$ & 25 & 23 & 24 & 24 & 23 & 22 & 22 \\
- Jumlah Bank & 262 & 336 & 517 & 590 & 320 & 327 \\
- Jumlah Kantor & 138 & 150 & 155 & 158 & 163 & 163 & 161 \\
\hline \multicolumn{1}{|c|}{ Total Kantor } & 225 & 286 & 364 & 401 & 402 & 439 & 433 \\
\hline
\end{tabular}

Sumber: Statistik Perbankan Syariah (SPS), Juni 2015

Berdasarkan tabel 1.1 diatas, dapat diketahui bahwa perkembangan bank syariah di Indonesia dapat dilihat dari pertumbuhan jumlah bank syariah itu sendiri, terbukti hingga tahun 2015 terdapat 12 Bank Umum Syariah (BUS) dan 22 Bank Umum Konvensional yang memiliki Unit Usaha Syariah (UUS) dan 161 Bank Pembiayaan Rakyat Syariah (BPRS).
Kenaikan kuantitas BUS tersebut menandakan bahwa semakin banyak mesyarakat yang menggunakan produk dan jasa yang disediakan oleh BUS. Hal ini menyebabkan asumsi bahwa aspirasi dan harapan masyarakat terhadap bank syariah dalam menjalankan semua transaksi sesuai dengan prinsip syariah menjadi semakin meningkat.

Pada perusahaan perbankan, pengungkapan informasi yang jelas dan terbuka sangatlah penting, khususnya mengenai kegiatan sosial, ekonomi, dan kekuasaan politik yang telah disalurkan oleh individu dan kelompok dalam suatu masyarakat, melalui manusia, sumber daya keuangan dan non-keuangan. Hal tersebut dikarenakan kejelasan dan keterbukaan informasi dari perusahaan digunakan sebagai bahan pertimbangan dalam mengamil keputusan. Dengan demikian, ruang lingkup dan tujuan dari laporan tanggung jawab perusahaan dapat memberikan informasi yang relevan dan handal yang akan memungkinkan perusahaan untuk membuat penilaian sosial-ekonomi. Salah satu dimensi pelaporan perusahaan yang penting untuk pengambilan keputusan adalah pelaporan sosial (Othman et al, 2009).

Selain itu, dalam suatu entitas Islam, para Muslim dalam mengambil suatu keputusan mengharapkan perusahaan yang tidak hanya mengungkapkan informasi yang akan membantu dalam membuat keputusan 
Baidok, et al/Jurnal Ekonomi Syariah Teori dan Terapan Vol. 3 No. 12 Desember 2016: 1020-1034; PENGARUH DEWAN KOMISARIS, KOMPOSISI DEWAN KOMISARIS INDEPENDEN, DEWAN PENGAWAS SYARIAH, FREKUENSI RAPAT DEWAN KOMISARIS SYARIAH, DAN FREKUENSI RAPAT KOMITE AUDIT TERHADAP PENGUNGKAPAN INDEKS ISLAMIC SOCIAL REPORTING PADA BANK UMUM SYARIAH PERIODE 2010-2014

sosial-ekonomi saja, tetapi juga keputusan

agama untuk memenuhi kebutuhan rohani dan spiritual. Haniffa (2002) menyarankan bahwa pengungkapan informasi penuh dalam laporan tahunan yang relevan dan handal akan membantu para pemangku kepentingan Muslim dalam mengambil keputusan sosial, ekonomi dan agama serta membantu manajemen perusahaan dalam memenuhi kewajiban kepada Allah SWT dan masyarakat yang disebut sebagai Islamic Social Reporting (ISR). Islamic Social Reporting adalah perluasan dari standar pelporan kinerja sosial yang meliputi harapan masyarakat tidak hanya mengeni peran perusahaan dalam perekonomian tetapi juga peran perusahaan dalam perspektif spiritual.

Salah satu faktor yang mempengaruhi pengungkapan ISR adalah Good Corporate Governance (GCG). Good corporate governance adalah suatu tata kelola bank syariahyang menerapkan prinsip-prinsip keterbukaan (transparency), akuntabilitas (accountability), pertanggungjawaban (responsibility), professional(professional), dan kewajaran (fairness) (Rustam, 2013:397). Pada penelitian ini, membahasmengenai struktur GCG yang terdiri dari dewan komisaris, komposisi dewan komisaris independen dan dewan pengawas syariah, serta mekanisme pengawasan GCG yang meliputi frekuensi rapat dewan pegawas syariah dan frekuensi rapat komite audit.
Berdasarkan uraian latar belakang di atas, maka peneliti merumuskan masalah penelitian sebagian berikut:

1. Apakah Dewan Komisaris, Komposisi Dewan Komisaris Independen, Dewan Direksi, Dewan Pengawas Syariah, Frekuensi Rapat Dewan Pengawas Syariah dan Frekuensi Rapat Komite Audit secara simultan berpengaruh signifikan terhadap Islamic Social Reporting (ISR)?

2. Apakah Dewan Komisaris secara parsial berpengaruh signifikan terhadap Islamic Social Reporting (ISR)?

3. Apakah Komposisi Dewan Komisaris Independen secara parsial berpengaruh signifikan terhadap Islamic Social Reporting (ISR)?

4. Apakah Dewan Pengawas Syariah secara parsial berpengaruh signifikan terhadap Islamic Social Reporting (ISR)?

5. Apakah Frekuensi Rapat Dewan Pengawas Syariah secara parsial berpengaruh signifikan terhadap Islamic Social Reporting (ISR)?

6. Apakah Frekuensi Rapat Komite Audit secara parsial berpengaruh signifikan terhadap Islamic Social Reporting (ISR)? Adapun tujuan penelitian ini adalah:

1. Untuk mengetahui dan menganalisa pengaruh Dewan Komisaris, Komposisi Dewan Komisaris Independen, Dewan Direksi, Dewan Pengawas Syariah, Frekuensi Rapat Dewan Pengawas Syariah dan Frekuensi Rapat Komite Audit secara simultan terhadap Islamic Social Reporting (ISR). 
Baidok, et al/Jurnal Ekonomi Syariah Teori dan Terapan Vol. 3 No. 12 Desember 2016: 1020-1034; PENGARUH DEWAN KOMISARIS, KOMPOSISI DEWAN KOMISARIS INDEPENDEN, DEWAN PENGAWAS SYARIAH, FREKUENSI RAPAT DEWAN KOMISARIS SYARIAH, DAN FREKUENSI RAPAT KOMITE AUDIT TERHADAP PENGUNGKAPAN INDEKS ISLAMIC SOCIAL REPORTING PADA BANK UMUM SYARIAH PERIODE 2010-2014

2. Untuk mengetahui dan menganalisa pengaruh Dewan Komisaris secara parsial terhadap Islamic Social Reporting (ISR).

3. Untuk mengetahui dan menganalisa pengaruh Komposisi Dewan Komisaris Independen secara parsial terhadap Islamic Social Reporting (ISR).

4. Untuk mengetahui dan menganalisa pengaruh Dewan Pengawas Syariah secara parsial terhadap Islamic Social Reporting (ISR).

5. Untuk mengetahui dan menganalisa pengaruh Frekuensi Rapat Dewan Pengawas Syariah secara parsial terhadap Islamic Social Reporting (ISR).

6. Untuk mengetahui dan menganalisa pengaruh Frekuensi Rapat Komite Audit secara parsial terhadap Islamic Social Reporting (ISR).

\section{LANDASAN PUSTAKA}

Bank syariah atau selanjutnya disebut bank Islam menurut Rivai dkk (2007:758-759) adalah bank yang melaksanakan kegiatan usahanya berdasarkan prinsip Islam, yaitu aturan perjanjian (akad) antara bank dengan pihak lain (nasabah) berdasarkan hukum Islam.Menurut Ismail (2011:51), terdapat beberapa jenis bank syariah yang ditinjau dari segi fungsinya, yaitu:

1. Bank Umum Syariah

Bank Umum Syariah (BUS) adalah bank yang melaksanakan kegiatan usaha sesuai dengan prinsip syariah dan melaksanakan kegiatan lalu lintas pembayaran (Ismail, 2011:51-52). 2. Unit Usaha Syariah
Unit Usaha Syariah (UUS) adalah unit usaha yang dibentuk oleh bank konvensional tetapi dengan kegiatan usaha yang sesuai dengan prinsip syariah dan melaksanakan kegiatan lalu lintas pembayaran (Ismail, 2011 :53-54).

3. Bank Pembiayaan Rakyat Syariah Bank Pembiayaan Rakyat Syariah (BPRS) adalah bank yang melaksanakan kegiatan usaha sesuai dengan prinsip syariah tanpa melaksanakan kegiatan lalu lintas pembayaran (Ismail, 2011:54).

Machmud dan Rukmana (2010:77) menyatakan,

"Good Corporate Governance (GCG) berarti suatu proses dan struktur yang digunakan untuk mengarahkan dan mengelola bisnis dan akuntabilitas perusahaan dengan tujuan utama mempertinggi nilai saham dalam jangka panjang dengan tetap memperhatikan kepentingan stakeholder lain."

Menurut KNKG (2006), struktur perusahaan yang terdiri dari Rapat Umum Pemegang Saham (RUPS), Dewan Komisaris, Dewan Pengawas Syariah, Direksi dan komite-komite di bawah Dewan Komisaris dan Direksi, mempunyai peran penting dalam pelaksanaan GCG secara efektif. Mekanisme Corporate Governance adalah suatu cara yang ditempuh berbagai pihak yang memiliki kepentingan terhadap suatu badan usaha untuk dapat memastikan bahwa pihak manajer dan pihak internal badan usaha lainnya dapat memenuhi kepentingan stakeholders. Mekanisme pengawasan GCG berupa frekuensi rapat yang dilakukan oleh Dewan Komisaris, DPS, Direksi dan Komite-komite di bawah Dewan Komisaris dan Direksi. 
Baidok, et al/Jurnal Ekonomi Syariah Teori dan Terapan Vol. 3 No. 12 Desember 2016: 1020-1034; PENGARUH DEWAN KOMISARIS, KOMPOSISI DEWAN KOMISARIS INDEPENDEN, DEWAN PENGAWAS SYARIAH, FREKUENSI RAPAT DEWAN KOMISARIS SYARIAH, DAN FREKUENSI RAPAT KOMITE AUDIT TERHADAP PENGUNGKAPAN INDEKS ISLAMIC SOCIAL REPORTING PADA BANK UMUM SYARIAH PERIODE 2010-2014

Terdapat tiga struktur dan dua mekanisme pengawasan sehubungan dengan GCG yang dibahas dalam penelitian ini, diantaranya adalah sebagai berikut:

1. Dewan Komisaris

Rustam (2013:400) menyatakan bahwa,

"Dewan komisaris adalah organ perseroan yang bertugas melakukan pengawasan secara umum dan atau khusus sesuai dengan anggaran dasar serta memberi nasihat kepada direksi sebagaimana dimaksud dalam Undang-Undang (UU) Nomor 40 tahun 2007 tentang Perseroan Terbatas; jumlah, komposisi, kriteria, rangkap jabatan, hubungan kelvarga, dan persyaratan lain bagi anggota dewan komisaris tunduk kepada ketentuan otoritas terkait."

2. Komposisi Dewan Komisaris Independen

Berdasarkan Peraturan Bank Indonesia Nomor 11/33/PBI/2009 tentang Pelaksanaan Good Corporate Governance bagi Bank Umum Syariah dan Unit Usaha Syariah, komisaris independen adalah anggota dewan komisaris yang tidak memiliki hubungan keuangan, kepengurusan, kepemilikan saham dan atau hubungan kelvarga dengan anggota dewan komisaris lainnya, direksi dan atau pemegang saham pengendali atau hubungan lain yang dapat mempengaruhi kemampuannya untuk bertindak independen.

3. Dewan Pengawas Syariah
Rustam (2013:414) menyatakan bahwa,

"Dewan Pengawas Syariah (DPS) adalah dewan yang bertugas memberikan nasihat dan saran kepada direksi serta mengawasi kegiatan bank agar sesuai dengan prinsip syariah."

4. Frekuensi Rapat Dewan Pengawas Syariah

Rustam (2013:428) menyatakan bahwa,

"Pengungkapan mengenai frekuensi rapat anggota dewan pengawas syariah paling tidak mencakup jumlah rapat yang diselenggarakan dalam satu tahun; tingkat kehadiran masingmasing anggota disetiap rapat yang dihadiri, baik secara fisik maupun melalui teknologi telekonferensi"

5. Frekuensi Rapat Komite Audit

Dalam menjalankan fungsi, tugas dan tanggung jawabnya, komite audit dapat mengadakan rapat secara periodik sebagaimana ditetapkan oleh komite audit sendiri. Dalam rapatnya, komite audit dapat meninjau akurasi pelaporan keuangan atau mendiskusikan isu-isu signifikan telah dikomunikasikan dengan manajemen, tetapi menurut penilaian komite audit memerlukan tindakan yang lebih lanjut (De Zoort et al, 2002).

Secara khusus, indeks ISR adalah perluasan dari standar pelaporan kinerja sosial yang meliputi harapan masyarakat tidak hanya mengenai peran perusahaan dalam 
Baidok, et al/Jurnal Ekonomi Syariah Teori dan Terapan Vol. 3 No. 12 Desember 2016: 1020-1034; PENGARUH DEWAN KOMISARIS, KOMPOSISI DEWAN KOMISARIS INDEPENDEN, DEWAN PENGAWAS SYARIAH, FREKUENSI RAPAT DEWAN KOMISARIS SYARIAH, DAN FREKUENSI RAPAT KOMITE AUDIT TERHADAP PENGUNGKAPAN INDEKS ISLAMIC SOCIAL REPORTING PADA BANK UMUM SYARIAH PERIODE 2010-2014

perekonomian, tetapi juga peran perusahaan dalam perspektif spiritual. Menurut Haniffa (2002), tujuan ISR adalah sebagai bentuk akuntabilitas kepada Allah SWT dan masyarakat serta meningkatkan transparansi kegiatan bisnis dengan menyajikan informasi yang relevan dengan memperhatikan kebutuhan spiritual investor muslim atau kepatuhan syariah dalam pengambilan keputusan.

Haniffa (2002) menjelaskan bahwa ada lima tema pengungkapan Indeks ISR, yaitu Tema Pendanaan dan Investasi, Tema Produk dan Jasa, Tema Karyawan, Tema Masyarakat, dan Tema Lingkungan Hidup. Kemudian dikembangkan oleh Othmanet al (2009) dengan menambahkan satu tema pengungkapan yaitu tema Tata Kelola Perusahaan.

Hipotesis

$\mathrm{Hl}$ : Dewan komisaris, komposisi dewan komisaris independen, dewan pengawas syariah, frekuensi rapat dewan pengawas syariah, dan frekuensi rapat komite audit secara simultan terhadap Islamic Social Reporting (ISR)

H2: Dewan Komisaris berpengaruh signifikan terhadap Islamic Social Reporting (ISR)

H3: Komposisi Dewan Komisaris Independen berpengaruh signifikan terhadap Islamic Social Reporting (ISR)

H4: Dewan Pengawas Syariah berpengaruh signifikan terhadap Islamic Social Reporting (ISR)

H5: Frekuensi Rapat Dewan Pengawas Syariah berpengaruh signifikan terhadap Islamic Social Reporting (ISR)

H6: Frekuensi Rapat Komite Audit berpengaruh signifikan terhadap Islamic Social Reporting (ISR)

\section{Model Analisis}

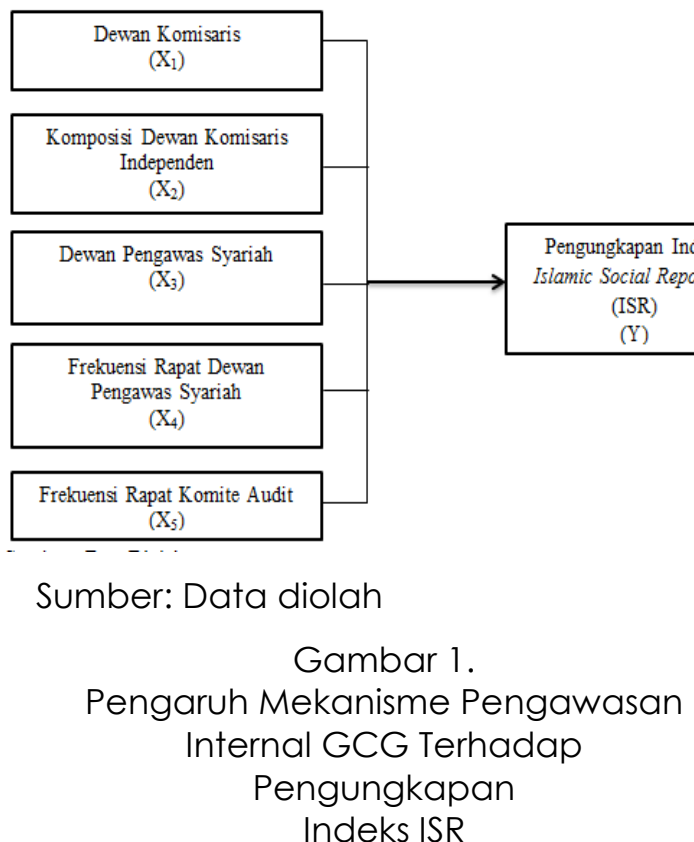

\section{METODE PENELITIAN}

\section{Pendekatan Penelitian}

Penelitian ini menggunakan pendekatan kuantitatif untuk menjawab masalah yang telah dirumuskan sebelumnya dan memerlukan perhitungan yang bersifat matematis dengan menggunakan rumus statistik tertentu.

\section{Identifikasi Variabel}


Baidok, et al/Jurnal Ekonomi Syariah Teori dan Terapan Vol. 3 No. 12 Desember 2016: 1020-1034; PENGARUH DEWAN KOMISARIS, KOMPOSISI DEWAN KOMISARIS INDEPENDEN, DEWAN PENGAWAS SYARIAH, FREKUENSI RAPAT DEWAN KOMISARIS SYARIAH, DAN FREKUENSI RAPAT KOMITE AUDIT TERHADAP PENGUNGKAPAN INDEKS ISLAMIC SOCIAL REPORTING PADA BANK UMUM SYARIAH PERIODE 2010-2014

Untuk menjawab rumusan masalah dan menguji hipotesis, maka variabel independen yang digunakan dalam penelitian ini adalah Good Corporate Governance (GCG) yang diukur dengan: Dewan Komisaris $\left(X_{1}\right)$, Komposisi Dewan Komisaris Independen $\left(\mathrm{X}_{2}\right)$, Dewan Pengawas Syariah $\left(X_{3}\right)$, Frekuensi Rapat Dewan Pengawas Syariah $\left(X_{4}\right)$, dan Frekuensi Rapat Komite Audit $\left(X_{5}\right)$. Variabel dependennya adalah pengungkapan Indeks Islamic Social Reporting (ISR) (Y).

\section{Definisi Operasional}

Untuk memberikan gambaran yang jelas mengenai variabel yang digunakan dalam penelitian ini, maka variabel tersebut dapat didefinisikan sebagai berikut:

1. Dewan Komisaris

Khoirudin (2013) menyatakan bahwa dewan komisaris diukur dengan menghitung jumlah anggota dewan komisaris dalam suatu perusahaan. Jumlah dewan komisaris diperoleh dari laporan GCG pada anuval report BUS periode 2010-2014 dengan menggunakan skala rasio dengan data nominal.

2. Komposisi Dewan Komisaris Independen

Gestari (2014) menyatakan bahwa komposisi dewan komisaris independen diukur dengan menghitung jumlah anggota komisaris independen dibagi total anggota dewan komisaris dalam suatu perusahaan dikali $100 \%$.
Komposisi dewan komisaris independen diperoleh dari laporan GCG pada anuval report BUS periode 2010-2014 dengan menggunakan skala rasio.

3. Dewan Pengawas Syariah

Khoirudin (2013) menyatakan bahwa dewan pengawas syariah dapat diukur dengan menghitung jumlah anggota dewan pengawas syariah dalam suatu perusahaan. Jumlah dewan pengawas syariah diperoleh dari laporan GCG pada anuval report BUS periode 2010-2014 dengan menggunakan skala rasio dengan data nominal.

4. Frekuensi Rapat Dewan Pengawas Syariah

Gestari (2014) menyatakan bahwa frekuensi rapat dewan pengawas syariah dapat diukur dengan menghitung jumlah rapat yang dilakukan dewan pengawas syariah pada suatu perusahaan. Rapat DPS membahas mengenai perkembangan produk maupun aktivitas kegiatan operasional di BUS. Jumlah frekuensi rapat dewan pengawas syariah diperoleh dari laporan GCG pada anuval report BUS periode 2010-2014 dengan menggunakan skala rasio dengan data nominal.

5. Frekuensi Rapat Komite Audit

Gestari (2014) menyatakan bahwa frekuensi rapat komite audit dapat diukur dengan menghitung jumlah rapat yang dilakukan komite audit 
Baidok, et al/Jurnal Ekonomi Syariah Teori dan Terapan Vol. 3 No. 12 Desember 2016: 1020-1034; PENGARUH DEWAN KOMISARIS, KOMPOSISI DEWAN KOMISARIS INDEPENDEN, DEWAN PENGAWAS SYARIAH, FREKUENSI RAPAT DEWAN KOMISARIS SYARIAH, DAN FREKUENSI RAPAT KOMITE AUDIT TERHADAP PENGUNGKAPAN INDEKS ISLAMIC SOCIAL REPORTING PADA BANK UMUM SYARIAH PERIODE 2010-2014

pada suatu perusahaan. Rapat Komite

Audit membahas mengenai risalah rapat dan pengesahannya, serta halhal yang perlu ditindaklanjuti dari rapat sebelumnya dan beberapa pembahasan lainnya. Jumlah frekuensi rapat komite audit diperoleh dari laporan GCG pada anuval report BUS periode 2010-2014 dengan menggunakan skala rasio dengan data nominal.

6. Islamic Social Reporting

Penilaian pengungkapan ISR berupa nilai (skor) yang diperoleh dari analisis tingkat pengungkapan Islamic Social Reporting (ISR). Penilaian indeks ISR dilakukan dengan menggunakan scoring dari nilai 0-1, dimana:

a. Nilai 0 jika tidak ada pengungkapan terkait item tersebut,

b. Nilai 1 jika ada pengungkapan terkait item tersebut.

Apabila seluruh item telah diungkapkan maka nilai maksimal yang dapat dicapai adalah sebesar 43. Othman, et al (2009) menyatakan, bahwa perhitungan indeks pengungkapan ISR dirumuskan sebagai berikut:

$I S R=$ Jumlah item yang diungkapkan perusahaan/Jumlah item yang diharapkan diungkapkan perusahaan $\times 100 \%$

Nilai ISR diperoleh dari annual report pada Bank Umum Syariah mulai tahun 2010 hingga 2014 dan skala pengukuran nilai ISR menggunakan skala rasio.

\section{Jenis dan Sumber Data}

Dalam penelitian ini, keseluruhan datanya adalah data sekunder yang diperoleh dari situs resmi BI (Bank Indonesia) yakni www.bi.go.id, yang meliputi laporan tata kelola perusahaan yang baik (good corporate governance), data tanggung jawab sosial (Corporate Social Responsibility) dan laporan kevangan (financial statement) berdasarkan annual report bank umum syariah, sehingga masing-masing nilai variabel yang digunakan dalam penelitian ini merupakan hasil perhitungan seluruh BUS di Indonesia. Data yang digunakan berupa data panel, yaitu gabungan data cross section sebanyak 6 BUS dan data time series (runtutan waktu) selama lima tahun yaitu mulai tahun 2010 hingga tahun 2014.

\section{Populasi dan Sampel}

Populasi yang digunakan dalam penelitian ini adalah seluruh Bank Umum Syariah (BUS) di Indonesia.Teknik pengambilan sampel dalam penelitian ini menggunakan teknik purposive sampling. Berikut kriteria yang digunakan untuk memilih sampel adalah sebagai berikut:

1. Bank Umum Syariah pada periode 2010-2014 yang menerbitkan laporan tahunannya melalui website masingmasing perusahaan perbankan syariah.

2. Bank Umum Syariah yang menerbitkan laporan tata kelola 
Baidok, et al/Jurnal Ekonomi Syariah Teori dan Terapan Vol. 3 No. 12 Desember 2016: 1020-1034; PENGARUH DEWAN KOMISARIS, KOMPOSISI DEWAN KOMISARIS INDEPENDEN, DEWAN PENGAWAS SYARIAH, FREKUENSI RAPAT DEWAN KOMISARIS SYARIAH, DAN FREKUENSI RAPAT KOMITE AUDIT TERHADAP PENGUNGKAPAN INDEKS ISLAMIC SOCIAL REPORTING PADA BANK UMUM SYARIAH PERIODE 2010-2014

perusahaannya lcorporate
governance), laporan tanggung
jawab sosialnya (Corporate Social
Reporting) dan laporan keuangan
padalaporan tahunan.

3. Bank Umum Syariah yang memiliki data yang lengkap terkait dengan variabel-variabel yang digunakan dalam penelitian ini.

Berdasarkan kriteria sampel yang telah ditentukan di atas, yang memenuhi kriteria sampel pada penelitian ini yaitu sebanyak 6 BUS untuk dianalisis selama lima tahun, sehingga total data dalam penelitian ini adalah 30 data.

\section{Teknik Analisis Data}

Teknik analisis data yang digunakan dalam penelitian ini adalah analisis statistik deskriptif, regresi data panel, koefisien determinasi $\left(R^{2}\right)$, uji hipotesis yang meliputi uji F dan uji t. Analisis deskriptif digunakan untuk mendeskripsikan suatudata dilihat dari mean, median, standar deviasi, nilai minimum dan nilai maksimum dengan menggunakan software Ms. Excel 2010. Regresi data panel untuk mengetahui pengaruh variabel independen terhadap variabel dependen secara simultan maupun parsial. Implikasi regresi data panel tidak harus dilakukan pengujian asumsi klasik (Ajija dkk, 2011:52). $\quad R^{2}$ digunakan untuk mengukur seberapa jauh komponen model dalam menerangkan variasi variabel dependen (Ghozali, 2011:97). Uji $F$ digunakan untuk mengetahui pengaruh variabel independen terhadap variabel dependen secara simultan (bersama-sama) sedangkan uji $†$ untuk mengetahui pengaruh variabel independen terhadap variabel dependen secara parsial.

\section{HASIL DAN PEMBAHASAN}

Tahap pengujian regresi data panel ada beberapa metode yang dapat dipilih adalah metode Common Effect Model (CEM), Fixed Effect Model (FEM), dan Random Effect Model (REM). Dalam menentukan estimasi model regresi data panel, dilakukan beberapa uji untuk memilih metode pendekatan estimasi yang sesuai. Langkah-langkah yang dilakukan dalam mendapatkan model yang yang tepat adalah dilakukan uji Chow Test dan dan uji Hausman Test.

Uji Chow Test merupakan pengujian untuk memilih kedua model diantara CEM dan FEM. Dari hasil pengujian Chow Test pada tabel 4.7, diperoleh nilai Probabilitas (Cross-section F) sebesar 0,0001 lebih kecil dari a $(0,05)$ sehingga dapat disimpulkan bahwa FEM lebih tepat dibandingkan dengan CEM.

Karena uji chow test memilih FEM, maka dilakukan pengujian selanjutnya yaitu Hausman Test untuk membandingkan antara FEM dengan REM. Dari hasil pengujian Hausman Test pada tabel 4.8, diperoleh nilai Probabilitas (Cross-section Random) sebesar 0,0000 lebih kecil dari a $(0,05)$ sehingga dapat disimpulkan bahwa FEM lebih tepat dibandingkan dengan REM.

Berdasarkan hasil pengujian pemilihan model data panel di atas, 
Baidok, et al/Jurnal Ekonomi Syariah Teori dan Terapan Vol. 3 No. 12 Desember 2016: 1020-1034; PENGARUH DEWAN KOMISARIS, KOMPOSISI DEWAN KOMISARIS INDEPENDEN, DEWAN PENGAWAS SYARIAH, FREKUENSI RAPAT DEWAN KOMISARIS SYARIAH, DAN FREKUENSI RAPAT KOMITE AUDIT TERHADAP PENGUNGKAPAN INDEKS ISLAMIC SOCIAL REPORTING PADA BANK UMUM SYARIAH PERIODE 2010-2014

maka dapat diambil kesimpulan bahwa metode analisis data panel yang paling tepat untuk menganalisis data panel dalam penelitian ini adalah Fixed Effect Model (FEM). Berikut ini adalah hasil estimasi dari persamaan regresi data panel dengan metode FEM:

Tabel 2.

Hasil Estimasi Fixed Effect Model (FEM)

Dependent Variable: ISR

Method: Panel Least Squares

Date: 04/15/16 Time: 10:16

Sample: 20102014

Periods included: 5

Cross-section included: 6

Total panel (balanced) observations: 30

\begin{tabular}{crrrr}
\hline \hline Variable & Coefficient & Std. Error & t-Statistic & Prob. \\
\hline \hline C & 6.562628 & 11.39464 & 0.575940 & 0.5714 \\
DK & 4.976506 & 2.696347 & 1.845647 & 0.0806 \\
KDKI & 0.363486 & 0.121959 & 2.980404 & 0.0077 \\
DPS & 5.541092 & 2.331364 & 2.376760 & 0.0281 \\
FRDPS & -0.401682 & 0.187169 & -2.146090 & 0.0450 \\
FRKA & -0.067893 & 0.115169 & -0.589504 & 0.5625 \\
\hline \hline \multicolumn{5}{c}{} \\
\hline \hline Cross-section fixed (dummy variables) \\
\hline \hline R-squared & Effects Specification & \\
Adjusted R-squared & 0.918319 & Mean dependent var & 56.12433 \\
S.E. of regression & 0.875329 & S.D. dependent var & 7.695857 \\
Sum squared resid & 2.717314 & Akaike info criterion & 5.113740 \\
Log likelihood & 140.2921 & Schwarz criterion & 5.627512 \\
F-statistic & -65.70609 & Hannan-Quinn criter. & 5.278100 \\
Prob(F-statistic) & 21.36122 & Durbin-Watson stat & 2.034610 \\
\hline \hline
\end{tabular}

Sumber: Data diolah

Berdasarkan hasil estimasi pada tabel 4.1 dapat ditulis bentuk persamaan liniernya sebagai berikut:

$|S R=6,562628+4,976506 \mathrm{DK}+0,363486 \mathrm{DK}|+5,5$

41092DPS-0,401682FRDPS-

$0,067893 F R K A$

Berdasarkan persamaan 1, maka hubungan antar variabel independen dan dependen dapat ditunjukkan sebagai berikut:

1. Apabila seluruh variabel independen tidak mengalami perubahan atau konstan, maka ISR sebesar 6,562628.

2. Apabila variabel DK mengalami peningkatan sebesar satu satuan sedangkan variabel independen lainnya dianggap konstan, maka ISR akan mengalami peningkatan sebesar 4,976506 satuan.

3. Apabila variabel KDKI mengalami peningkatan sebesar satu satuan sedangkan variabel independen lainnya dianggap konstan, maka ISR akan mengalami peningkatan sebesar 0,363486 satuan.

4. Apabila variabel DPS mengalami peningkatan sebesar satu satuan sedangkan variabel independen lainnya dianggap konstan, maka ISR akan mengalami peningkatan sebesar 5,541092 satuan.

5. Apabila variabel FRDPS mengalami peningkatan sebesar satu satuan sedangkan variabel independen lainnya dianggap konstan, maka ISR akan mengalami penurunan sebesar 0,401682 satuan.

6. Apabila variabel FRKA mengalami peningkatan sebesar satu satuan sedangkan variabel independen lainnya dianggap konstan, maka ISR akan mengalami penurunan sebesar 0,067893 satuan

Berdasarkan table 4.1, dapat diketahui bahwa nilai Adjusted R2 sebesar 0,8753329 . Hal ini menunjukkan bahwa variabel DK, KDKI, DPS, FRDPS dan FRKA dapat menjelaskan variabel ISR sebesar $87,53 \%$, sedangkan sisanya sebesar $12,47 \%$ dijelaskan oleh variabel-variabel lain diluar model atau diluar variabel-variabel yang diteliti. 
Baidok, et al/Jurnal Ekonomi Syariah Teori dan Terapan Vol. 3 No. 12 Desember 2016: 1020-1034; PENGARUH DEWAN KOMISARIS, KOMPOSISI DEWAN KOMISARIS INDEPENDEN, DEWAN PENGAWAS SYARIAH, FREKUENSI RAPAT DEWAN KOMISARIS SYARIAH, DAN FREKUENSI RAPAT KOMITE AUDIT TERHADAP PENGUNGKAPAN INDEKS ISLAMIC SOCIAL REPORTING PADA BANK UMUM SYARIAH PERIODE 2010-2014

Uji F

Berdasarkan tabel 4.1, diketahui tingkat probabilitas (F-statistic) sebesar 0,000000 yang lebih kecil dari a $(0,05)$, sehingga $\mathrm{H}_{0}$ ditolak dan dapat disimpulkan bahwa DK, KDKI, DPS, FRDPS, dan FRKA secara simultan berpengaruh signifikan terhadap ISR.

Hasil Penelelitian menunjukkan bahwa Mekanisme Pengawasan internal GCG mempunyai peran penting dalam BUS, dimana dalam pelaksanaannya, BUS dituntut untuk selalu beroperasi secara efisien agar pengawasan tersebut bejalan secara efektif, sehingga pengungkapan ISR akan semakin optimal. Hasil penelitian ini mendukung penelitian yang dilakukan oleh Gestari (2014) yang menyatakan bahwa DK, KDKI, DPS, FRDPS, dan FRKA secara simultan berpengaruh signiikan terhadap ISR.

Setiap manusia dalam melakukan pengawasan harus sesuai dengan ajaran Islam, yaitu meluruskan yang tidak lurus, mengoreksi yang salah dan membenarkan apa yang hak. Sebagaimana firman Allah yang menjelaskan pengenai pentingnya pengawasan dalam Al-Qur'an surat AlMujadalah ayat 7 :

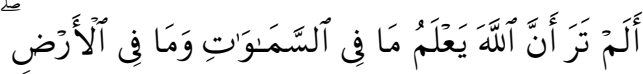

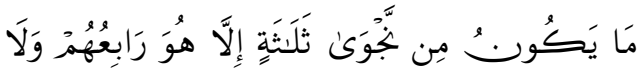

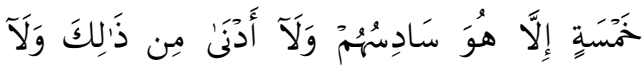
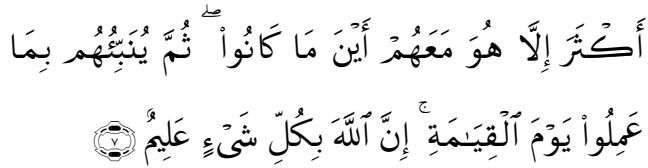

'A-lam tara'anna llāha ya lamu mā fi s-samāwāti wa-mā fî l- 'arḍi mā yakūnu min najwā thalāthatin 'illā huwa rābi 'uhum wa-lā khamsatin 'illā huwa sādisuhum wa-lā 'adnā min żālika walā 'akTara 'illā huwa ma 'ahum 'ayna mā kānūTumma yunabbi'uhum bimā 'amilū yawma l-qiyāmati inna llāha bi-kulli syay'in 'allimun.

Artinya: "Tidakkah kamu perhatikan, bahwa Sesungguhnya Allah mengetahui apa yang ada di langit dan di bumi? tiada pembicaraan rahasia antara tiga orang, melainkan Dia-lah keempatnya. dan tiada (pembicaraan antara) lima orang, melainkan Dia-lah keenamnya. dan tiada (pula) pembicaraan antara jumlah yang kurang dari itu atau lebih banyak, melainkan Dia berada bersama mereka di manapun mereka berada. kemudian Dia akan memberitahukan kepada mereka pada hari kiamat apa yang telah mereka kerjakan. Sesungguhnya Allah Maha mengetahui segala sesuatu."(Q.S. 58:7, Departemen agama RI, 2010:543)

Uji

Berdasarkan tabel 4.1, diketahui bahwa variabel DK memiliki tingkat probabilitas (t-statistic) sebesar 0,0806 yang lebih besar dari a $(0,05)$. Hal ini berarti secara parsial DK tidak berpengaruh signifikan terhadap ISR. alasannya dapat disebabkan karena dalam pelaksanakan tugasnya, dewan komisaris tidak selalu menetap (cenderung pasif), tidak dapat memantau secara langsung, sehingga kurang mendukung berlangsungnya pengungkapan ISR dalam bank umum syariah. Hasil penelitian ini tidak mendukung penelitian yang dilakukan 
Baidok, et al/Jurnal Ekonomi Syariah Teori dan Terapan Vol. 3 No. 12 Desember 2016: 1020-1034; PENGARUH DEWAN KOMISARIS, KOMPOSISI DEWAN KOMISARIS INDEPENDEN, DEWAN PENGAWAS SYARIAH, FREKUENSI RAPAT DEWAN KOMISARIS SYARIAH, DAN FREKUENSI RAPAT KOMITE AUDIT TERHADAP PENGUNGKAPAN INDEKS ISLAMIC SOCIAL REPORTING PADA BANK UMUM SYARIAH PERIODE 2010-2014

oleh Khoirudin (2013) dan Gestari (2014)

independen pada BUS dapat yang menyatakan bahwa DK meningkatkan perlindungan bagi berpengaruh signifikan terhadap ISR. kepentingan pemangku khususnya sebagaimana dikaitkan dengan fungsi akuntabilitas, dewan komisaris dituntut dalam mengawasi manajemen dalam mengelola perusahaan dengan baik, sesuai dengan Q.S Al-Isra' ayat 84:

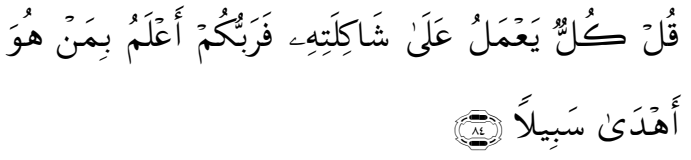

Qul kullun-ya'malu 'alā syākilatihī farabbukum 'a lamu bi-man huwa 'ahdā sabilān.

Artinya: "Katakanlah: "Tiap-tiap orang berbuat menurut keadaannya masingmasing". Maka Tuhanmu lebih mengetahui siapa yang lebih benar jalanNya." (Q.S. 17:84, Departemen agama Rl, 2010:290)

Berdasarkan uji t, diketahui bahwa

variabel KDKI memiliki tingkat probabilitas (t-statistic) sebesar 0,0077 yang lebih kecil dari a $(0,05)$. Hal ini berarti secara parsial KDKI berpengaruh signifikan terhadap ISR. Pengaruh signifikan ini dapat disebabkan oleh rata-rata KDKI pada BUS selama periode 2010-2014 sebesar 63,46\%. Berdasarkan peraturan Bank Indonesia Nomor 11/33/PBI/2009 tentang pelaksanaan Good Corporate Governance bagi Bank Umum Syariah dan Unit Usaha Syariah menyatakan bahwa anggota dewan komisaris independen minimal 50\% dari anggota dewan komisaris. Hal ini menunjukkan jumlah dan komposisi dari komisaris independen telah sesuai dengan ketentuan yang berlaku, sehingga dapat disimpulkan bahwa keberadaan komisaris nasabah pemilik dana dan pemegang saham minoritas dan menghindari benturan kepentingan dalam pelaksanaan tugas serta memberikan kontribusi yang efektif terhadap hasil dari proses penyusunan laporan keuangan yang berkualitas atau kemungkinan terhindar dari kecurangan laporan keuangan. Hasil penelitian ini mendukung penelitian yang dilakukan oleh Gestari (2014) yang menyatakan bahwa komposisi dewan komisaris independen berpengaruh signifikan terhadap ISR. Adapun ayat yang berkaitan dengan peranan dewan komisaris independen dalam sebuah perusahaan yang dijelaskan dalam Q.S An-Nisa' ayat 135.

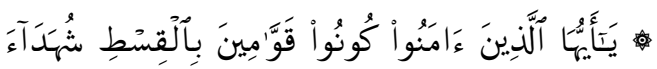

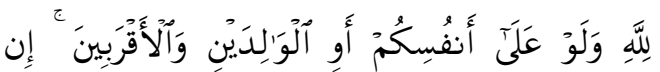

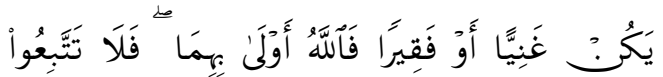

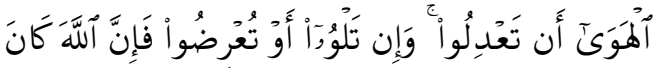

$$
\begin{aligned}
& \text { بِمَا تَعَمَلُونَ خَبِيرًا }
\end{aligned}
$$

Yā-'ayyuhā llażīna 'āmanū kūnū qawwāminna bi---qisți syuhadā'a li-llāhi wa-law 'alā'anfusikum 'awi wālidayni wa-l-'aqrabina in yakun ghaniyyan 'aw faqīran fa-llāhu 'awlā bihimā fa-lā tattabi ú I-hawā'an ta 'dilū wa-'in talwū 'aw tu 'rị̣u fa-'inna llāha kāna bi-mā ta 'malūna khabīran. Artinya: "Wahai orang-orang yang beriman, jadilah kamu orang yang benar-benar penegak keadilan, menjadi saksi karena Allah biarpun terhadap dirimu sendiri atau ibu bapa dan kaum kerabatmu. jika ia Kaya 
Baidok, et al/Jurnal Ekonomi Syariah Teori dan Terapan Vol. 3 No. 12 Desember 2016: 1020-1034; PENGARUH DEWAN KOMISARIS, KOMPOSISI DEWAN KOMISARIS INDEPENDEN, DEWAN PENGAWAS SYARIAH, FREKUENSI RAPAT DEWAN KOMISARIS SYARIAH, DAN FREKUENSI RAPAT KOMITE AUDIT TERHADAP PENGUNGKAPAN INDEKS ISLAMIC SOCIAL REPORTING PADA BANK UMUM SYARIAH PERIODE 2010-2014

ataupun miskin, Maka Allah lebih tahu kemaslahatannya. Maka janganlah kamu mengikuti hawa nafsu karena ingin menyimpang dari kebenaran.dan jika kamu memutar balikkan (kata-kata) atau enggan menjadi saksi, Maka Sesungguhnya Allah adalah Maha mengetahui segala apa yang kamu kerjakan."(Q.S. 04:135, Departemen agama RI, 2010:100)

Berdasarkan uji t, diketahui bahwa variabel DPS memiliki tingkat probabilitas (t-statistic) sebesar 0,0281 yang lebih kecil dari a $(0,05)$. Hal ini berarti secara parsial DPS berpengaruh signifikan terhadap ISR. Pengaruh signifikan ini dapat disebabkan oleh tugas DPS yang dituntut aktif dalam melakukan supervisi, mengumpulkan data, menganalisis dan melakukan koreksi terhadap berbagai temuan ketidakpatuhan syariah pada sebuah bank syariah yang diungkapkan dalam pelaporan sosial secara syariah. Hasil penelitian ini mendukung penelitian yang dilakukan oleh Ningrum dkk (2013) yang menyatakan bahwa DPS berpengaruh signifikan terhadap ISR.

DPS diberi kekuasaan dan wewenang yang luas untuk menelaah setiap kontrak, metode, atau aktivitas yang berkenaan dengan aturan-aturan pada kepatuhan Syariah BUS. Allah berfirman dalam Q.S As-Sajadah ayat 5.

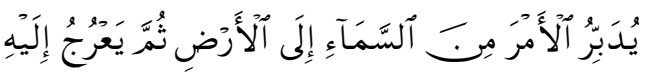

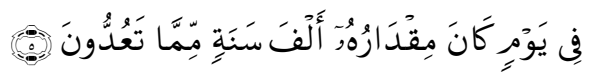

Yudabbiru l- 'amra mina s-samāi 'ilā l'arḍi thumma ya 'ruju 'ilayhi fi yawmin kāna miqdāruhū'alfa sanatin mimmā ta uddūna.
Artinya: "Dia mengatur urusan dari langit ke bumi, kemudian (urusan) itu naik kepadanya dalam satu hari yang kadarnya adalah seribu tahun menurut perhitunganmu." (Q.S. 32:5, Departemen agama Rl, 2010:415)

Berdasarkan uji t, diketahui bahwa variabel FRDPS memiliki tingkat probabilitas (t-statistic) sebesar 0,0450 yang lebih kecil dari a $(0,05)$. Hal ini berarti secara parsial FRDPS berpengaruh signifikan terhadap ISR. Pengaruh signifikan ini dapat disebabkan oleh semakin intens-nya DPS dalam melakukan pertemuan atau rapat, maka tidak menutup kemungkinan koordinasi DPS akan semakin baik dan pengawasan akan semakin efektif sesuai prinsip syariah serta DPS akan sering memberikan kontribusi atau masukan-masukan kepada pihak manajemen dalam hal penyaluran dana sosial sehingga pengungkapan ISR akan lebih luas. Hasil penelitian ini mendukung penelitian yang dilakukan oleh Gestari (2014) yang menyatakan bahwa FRDPS berpengaruh signifikan terhadap ISR.adapun ayat Al-Qur'an yang menjelaskan mengenai rapat DPS dilakukan secara bermusyawarah dalam mencapai mufakat, yang dijelaskan dalam Q.S Al-Imran ayat 159

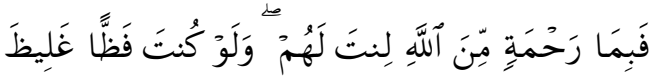

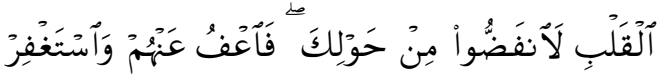

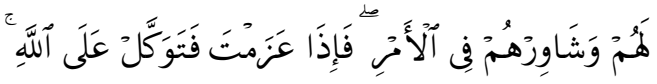

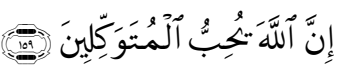

Fa-bi-mā raḥmatin mina Ilāhi linta lahum wa-law kunta fazzzan ghaliza lqalbi la-nfaḍḍ̄ min hawlika fa-'fu 
Baidok, et al/Jurnal Ekonomi Syariah Teori dan Terapan Vol. 3 No. 12 Desember 2016: 1020-1034; PENGARUH DEWAN KOMISARIS, KOMPOSISI DEWAN KOMISARIS INDEPENDEN, DEWAN PENGAWAS SYARIAH, FREKUENSI RAPAT DEWAN KOMISARIS SYARIAH, DAN FREKUENSI RAPAT KOMITE AUDIT TERHADAP PENGUNGKAPAN INDEKS ISLAMIC SOCIAL REPORTING PADA BANK UMUM SYARIAH PERIODE 2010-2014

'anhum wa-staghfir lahum wasyāwirhum fì l-'amri fa-'idhā'azamta fa-tawakkal 'alā llāhi inna llāha yuhibbu l-mutawakkilina.

Artinya: "Maka disebabkan rahmat dari Allah-lah kamu Berlaku lemah lembut terhadap mereka. Sekiranya kamu bersikap keras lagi berhati kasar, tentulah mereka menjauhkan diri dari sekelilingmu.karena itu ma'afkanlah mereka, mohonkanlah ampun bagi mereka, dan bermusyawarahlah dengan mereka dalam urusan itu. Kemudian apabila kamu telah membulatkan tekad, Maka bertawakkallah kepada Allah.Sesungguhnya Allah menyukai orang-orang yang bertawakkal kepada-Nya."(Q.S. 03:159,

Departemen agama RI, 2010:71)

Berdasarkan uji t, diketahui bahwa variabel FRKA memiliki tingkat probabilitas (t-statistic) sebesar 0,5625 yang lebih besar dari a $(0,05)$. Hal ini berarti secara parsial FRKA tidak berpengaruh signifikan terhadap ISR. Hal ini dapat disebabkan oleh tingkat frekuensi atau jumlah pertemuan yang dilakukan oleh komite audit tidak menjamin bahwa pelaksanaan monitoring terhadap manajemen untuk melakukan kecurangan akan berjalan secara efektif, sehingga peluang manajemen untuk melakukan kecurangan denganmenyembunyikan informasi masih dapat dimungkinkan. Hasil penelitian ini tidak mendukung penelitian yang dilakukan oleh Gestari (2014) yang menyatakan bahwa frekuensi rapat komite audit berpengaruh signifikan terhadap ISR.

Komite audit juga dituntut untuk memperhatikan suatu persoalan yang dituangkan pada sebuah rapat yang dilakukannya, berikut penjelasan mengenai perbeddan argumen pendapat yang biasa terjadi pada adanya suatu rapat musyawarah yang dijelaskan dalam Q.S An-Nahl ayat 125.

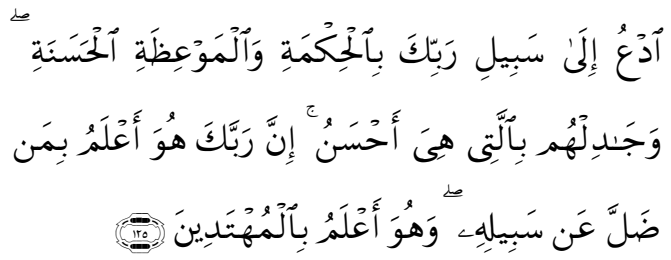

Ud 'u 'ilā sabili rabbika bi-l-hikmati waI-maw izati I-ḥasanati wa-jādilhum billatī hiya 'ahsanu 'inna rabbaka huwa 'a lamu bi-man dalla 'an sabilihì wahuwa 'a 'lamu bi-l-muhtadina.

Artinya: "Serulah (manusia) kepada jalan Tuhan-mu dengan hikmah dan pelajaran yang baik dan bantahlah mereka dengan cara yang baik. Sesungguhnya Tuhanmu Dialah yang lebih mengetahui tentang siapa yang tersesat dari jalan-Nya dan Dialah yang lebih mengetahui orang-orang yang mendapat petunjuk." (Q.S. 16:125, Departemen agama Rl, 2010:281)

\section{SIMPULAN}

Berdasarkan analisis hasil penelitian dapat disimpulkan sebagai berikut:

1. Dewan Komisaris, Komposisi Dewan Komisaris Independen, Dewan Pengawas Syariah, Frekuensi Rapat Dewan Pengawas Syariah, dan Frekuensi Rapat Komite Audit secara simultan berpengaruh signifikan terhadap Islamic Social Reporting (ISR) pada Bank Umum Syariah di Indonesia.

2. Dewan Komisaris dan Frekuensi Rapat Komite Audit secara parsial berpengaruh tidak signifikan terhadap Islamic Social Reporting (ISR) pada Bank Umum Syariah di Indonesia. 
Baidok, et al/Jurnal Ekonomi Syariah Teori dan Terapan Vol. 3 No. 12 Desember 2016: 1020-1034; PENGARUH DEWAN KOMISARIS, KOMPOSISI DEWAN KOMISARIS INDEPENDEN, DEWAN PENGAWAS SYARIAH, FREKUENSI RAPAT DEWAN KOMISARIS SYARIAH, DAN FREKUENSI RAPAT KOMITE AUDIT TERHADAP PENGUNGKAPAN INDEKS ISLAMIC SOCIAL REPORTING PADA BANK UMUM SYARIAH PERIODE 2010-2014

3. Komposisi Dewan Komisaris Independen, Dewan Pengawas Syariah, dan Frekuensi Rapat Dewan Pengawas Syariah secara parsial berpengaruh signifikan terhadap Islamic Social Reporting (ISR) pada Bank Umum Syariah di Indonesia.

\section{DAFTAR PUSTAKA}

Ajija, dkk. 2011. Cara Cerdas Menguasai Eviews. Jakarta. Salemba Empat.

Departemen Agama Republik Indonesia. 2010. Mushaf Al-Azhar: Al-Quran dan Terjemah. Bandung: Jabal Rodhotul Jannah.

De Zoort, et al. 2002. Audit Committee Effectiveness: A Synthesis of The Empirical Audit Committee literature. Journal of Accounting Literature, Vol 21.

Gestari, Intan. 2014. Pengaruh Good Corporate Governance dan Profitabilitas Terhadap Pengungkapan Islamic Social Reporting pada Bank Umum Syariah di Indonesia. Naskah Publikasi. Universitas Muhammadiyah Surakarta

Ghozali, Imam. 2011. Aplikasi Analisis Multivariate dengan Program IBM SPSS 19. Semarang: Universitas Diponegoro

Haniffa, Roszaini M. 2002. Social Responsibility Disclosure: An Islamic Perspective. Discussion Paper Vol. 1 No. 2. Reference of Publication

Ismail. 2011. Perbankan Syariah. Jakarta: Kencana.

Khoiruddin, Amirul .2013. Corporate Governance dan Pengungkapan Islamic Social Reporting pada Perbankan Syariah di Indonesia. Accounting Analysis Journal 2 (2), (Online),(http://journal.unnes.ac.id/sju/i ndex.php/aaj, diakses 20 Oktober 2015).

Komite Nasional Kebijakan Governance (KNKG). 2006. Pedoman Umum GCG di Indonesia.

Machmud, Amir dan Rukmana. 2010. Bank Syariah: Teori, Kebijakan dan Studi Empiris di Indonesia. Jakarta: Penerbit Erlangga.
Ningrum, Ratna Aditya dkk. 2013. Pengaruh Kinerja Keuangan, Kepemilikan Institusional Dan Ukuran Dewan Pengawas Syariah Terhadap Pengungkapan ISR. Accounting Analysis Journal 2 (4), (Online), (http://journal.unnes.ac.id/sju/index.ph p/aaj, diakses 20 Oktober 2015)

Othman, et al. 2009. "Determinants of Islamic Social Reporting Among Top Shariah-Approved Companies in Bursa Malaysia". Research Journal of International Studies Issue.12 Oktober 2009.

Republik Indonesia. Statistik Perbankan Syariah, Juni 2015, (Online), (www.bi.go.id, diakses 17 September 2015)

\begin{tabular}{ccc} 
& Peraturan Bank \\
\hline Indonesia Nomor $11 / 33 /$ PBI/2009
\end{tabular} tentang Pelaksanaan Good Corporate Governance bagi Bank Umum Syariah dan Unit Usaha Syariah, 2009. (Online), (www.ojk.go.id, diakses pada 21 November 2015)

Rivai, Veithzal dkk. 2007. Bank and Financial Institusional Management. Jakarta: Bank Indonesia.

Rizkiningsih, Priyesta. 2012. "Faktor-Faktor yang mempengaryuhi Islamic Social reporting (ISR): Studi Empiris pada Bnak Syariah di Indonesia, Malaysia dan Negara-Negara Gulf Cooperation Council". Skripsi. Universitas Diponegoro.

Rustam, Bambang Rianto. 2013. Manajemen Risiko Perbankan Syariah di Indonesia. Jakarta: Salemba Empat 